\title{
Magyarország, Csehország és Szlovákia regionális és makrogazdasági konvergenciája az EU-csatlakozás előtt és után ${ }^{1}$
}

\section{Regional and Macroeconomic Convergence of Hungary, Czechia and Slovakia Before and After the EU Accession}

\begin{abstract}
A 2004-es első keleti bővités mérföldkőnek tekinthető az Európai Unió (EU) történetében. Az új tagállamok felzárkóz(tat)ása stratégiai prioritássá vált az EU és a keletközép-európai országok számára egyaránt, hiszen a gazdasági/jövedelmi konvergencia az integrációs érettség egyik meghatározó területe. A konvergenciavizsgálat ezért elméleti és gyakorlati szempontból is egyaránt fontos. Tanulmányunkban a három visegrádi kis ország (Magyarország, Csehország és Szlovákia) regionális és makrogazdasági konvergenciájának alakulását vizsgáljuk különféle kvantitatív eszközök segítségével. Az elemzés eredményei meglehetösen ambivalensek. A tagállamokon belüli területi egyenlötlenségek nem csökkentek, a felzárkózás tekintetében viszont pozitiv eredmények figyelhetôk meg. A modellszámítás eredményei egyúttal felhívják a figyelmet a gazdasági növekedésnek az utolérésben játszott jelentőségére. A tanulmány következtetései továbbá összhangban vannak az egyéb empirikus eredményekkel is.
\end{abstract}

Kulcsszavak: konvergencia, felzárkózás, EU, Magyarország, Csehország, Szlovákia

Kollárik Ferenc, egyetemi tanársegéd, Nemzeti Közszolgálati Egyetem, Államtudományi és Nemzetközi Tanulmányok Kar, Közgazdaságtani és Nemzetközi Gazdaságtani Tanszék; doktorandusz, Budapesti Corvinus Egyetem, Nemzetközi Kapcsolatok és Politikatudományi Doktori Iskola, Világgazdasági alprogram; E-mail: Kollarik.Ferenc@uni-nke.hu.

Jelen publikáció az Európai Unió, Magyarország és az Európai Szociális Alap társfinanszírozása által biztosított forrásból az EFOP-3.6.3-VEKOP-16-2017-00007 azonosítószámú „Tehetségból fiatal kutatóA kutatói életpályát támogató tevékenységek a felsőoktatásban" című projekt keretében jött létre. 


\begin{abstract}
The first Eastern enlargement in 2004 was a milestone in the history of the European Union (EU). The catching up of the new Member States became a strategic priority for the EU and the Central and Eastern European countries as well. This is because economic convergence is a significant element of integration maturity. Therefore, convergence analysis is an important issue from both a theoretical and practical perspective. The study examines the regional and macroeconomic convergence of the three small Visegrad countries (Hungary, Czechia and Slovakia) using different quantitative methods. The result of the analysis are quite ambivalent. Regional disparities within the Member States have not decreased, however, positive results can be seen in terms of catching up. The results of the model draw the attention to the fact that economic growth plays a key role in the process of catching up. Furthermore, the conclusions are in line with other empirical results, too.
\end{abstract}

Keywords: convergence, catching up, EU, Hungary, Czechia, Slovakia

\title{
1. Bevezetés
}

Az Európai Unió (EU) első keleti bővítése az egyik legjelentősebb mérföldkő volt az integráció eddigi történetében. 2004. május 1-jén nyolc kelet-közép-európai állam - a négy visegrádi ország, a három balti állam és Szlovénia -, valamint két mediterrán szigetország - Ciprus és Málta - vált az EU teljes jogú tagjává. A csatlakozás több szempontból is meghatározó jelentőségú. Egyrészt ez volt az eddigi legnagyobb bővítési hullám, amelynek során egyszerre tíz ország nyert felvételt az EU-ba, ami a döntéshozatali mechanizmus jelentősebb átalakítását tette szükségessé. ${ }^{2}$ Másrészt olyan gazdaságok csatlakoztak az integrációhoz, amelyek gazdasági fejlettsége jócskán elmaradt az EU átlagától. ${ }^{3}$ A gazdasági, jövedelmi különbségek csökkentése, valamint a felzárkóz(tat)ás tehát stratégiai prioritássá vált mind az új, mind pedig a régi tagállamok számára. ${ }^{4}$ A konvergencia fokozása rendkívül fontos, hiszen egy megfelelő mértékủ gazdasági homogenitás az egyik elengedhetetlen előfeltétele egy valóban jól müködő regionális integrációnak. ${ }^{5}$ A reálkonvergencia erősítése hosszabb távon elősegíti magának az integrációs folyamatnak a gazdasági és politikai fenntarthatóságát. ${ }^{6}$ Szélesebb összefüggésben vizsgálva a kérdéskört azt mondhatjuk, hogy a makrogazdasági

2 Példaként említhető az „egy tagállam - egy biztos” rendszer bevezetése az Európai Bizottság összetétele és múködése kapcsán. Erről lásd bővebben például: Horváth Zoltán: Kézikönyv az Európai Unióról. Budapest, HVG-ORAC, 2011.

3 A lemaradás még nyilvánvalóbb, ha nem az európai uniós átlaghoz viszonyítunk, hanem az euróövezet átlagos fejlettségi szintjével vetjük össze a tíz ország gazdasági teljesítményét.

4 A problémát csak tovább fokozta a következő két - 2007-ben és 2013-ban bekövetkezett - keleti bővítés, amelynek során újabb három ország, Románia, Bulgária, valamint Horvátország csatlakozott az integrációhoz.

5 Természetesen arra vonatkozóan, hogy mit tekint(het)ünk megfelelő mértékủ homogenitásnak, nem adható egy mindenki által elfogadott egységes válasz. Annyi azonban bizonyos, hogy a jelentős különbségek negatívan befolyásolják az integráció hatékony működését, amit legjobban talán az euróövezeti válság bizonyított.

6 Halmai Péter: Konvergencia és felzárkózás az euróövezetben. Közgazdasági Szemle, 66. (2019), 687-712.

Európai Tükör 2020/2. 
konvergencia az integrációs fejlettség/érettség egyik fontos területe, amely elméleti és gyakorlati szempontból egyaránt meghatározó. A témával való foglalkozás ráadásul mindig releváns, hiszen a konvergenciafolyamat alakulásának nyomon követése a Gazdasági és Monetáris Unió (GMU) sikeres működése szempontjából is folyamatos feladatot jelent.

Tanulmányunkban arra keressük a választ, hogy hogyan alakult a regionális és a makrogazdasági konvergencia Magyarország, Csehország, valamint Szlovákia esetében az Európai Unióhoz történő csatlakozás előtti néhány évben, illetve az azóta eltelt időszakban. A vizsgálat ily módon a három kis visegrádi tagállam (szúkebb földrajzi értelemben vett regionális versenytársak) összehasonlító konvergenciaelemzése. A kiválasztott és vizsgált országok eseteiből levonható tapasztalatokkal és következtetésekkel így választ adhatunk arra a kérdésre is, hogy mennyiben értek célt az eddigi tagállami erőfeszítések, illetve hogy a konvergencia mely összefüggéseire lenne célszerű nagyobb figyelmet összpontosítani.

Módszertani szempontból a tanulmányban kvantitatív megközelítést alkalmazunk, és néhány egyszerû - a regionális gazdaságtanban is alkalmazott - statisztikai mutató és módszer (szigma-konvergencia, terjedelem, utolérési modellszámítás) segítségével vizsgáljuk a három visegrádi ország konvergenciafolyamatainak alakulását egy viszonylag hosszabb idősoron. Ennek segítségével egy átfogó képet kaphatunk a folyamatok múltbeli alakulásáról, jelenlegi állapotáról, valamint jövőbeli esélyeiről.

A bevezetést követő részben áttekintést adunk a konvergencia (és divergencia) főbb elméleti összefüggéseiről, valamint arról, hogy mindez mennyiben releváns az európai integráció vonatkozásában. Ennek kapcsán röviden kitérünk a regionális (kohéziós) politika, a Gazdasági és Monetáris Unió (GMU), valamint a konvergencia összefüggésére is. Ezt követően a tagországokon belüli (regionális) konvergencia alakulására összpontosítjuk a figyelmünket, majd az országok felzárkózási teljesítményeit elemezzük. Ennek kapcsán egy egyszerúbb modellszámítás segítségével több lehetséges utolérési pályát (forgatókönyvet) adunk meg az elkövetkező időszakra nézve. Végül a konvergenciát befolyásoló főbb gazdaságpolitikai összefüggéseket és empirikus eredményeket foglaljuk össze. A dolgozat az eredmények összegzésével, illetve a fontosabb következtetések levonásával zárul.

\section{A konvergencia elmélete és jelentősége az Európai Unióban}

A konvergencia fogalmát több tudomány(terület) is használja (társadalomtudományok, természettudományok, műszaki tudomány), jóllehet többnyire kissé eltérő tartalommal. ${ }^{7}$ A jelenség a közgazdaság-tudományban (azon belül is különösen a makroökonómiában és a regionális gazdaságtanban) általában két különböző jellegű folyamatot takar. Egyrészt jelentheti egy bizonyos referenciaértékhez történő közeledést, felzárkózást

Ferkelt Balázs: Konvergencia az eurózónában a közös pénz bevezetése előtt és után. EU Working Papers, (2005), 4. 1-15. 
vagy szélső esetben magát az utolérést. ${ }^{8}$ Másrészt utalhat különböző (gazdasági) entitások (országok, régiók stb.) között meglévő „átlagos” különbségek csökkenésére is. ${ }^{9}$ Már ebből is látható, hogy miért meghatározó jelentőségű a fogalom az (európai) integrációval kapcsolatos kutatásokban. A gazdaságilag kevésbé fejlett uniós tagországok felzárkóz(tat)ása a fejlettebb tagállamokhoz, valamint az országok közötti, illetve országokon belüli egyenlőtlenségek csökkentése már évtizedek óta kiemelt fontosságú célkitűzés az EU-ban.

A konvergenciaelmélet gyökere alapvetően a neoklasszikus növekedési modellben keresendő. A Robert Solow (1956) által kidolgozott elmélet egy elsőfokon homogén, állandó mérethozadékkal jellemezhető, kétváltozós termelési függvényből indul ki, amely tulajdonképpen a gazdaság rendelkezésére álló technológiát reprezentálja:

$$
\mathrm{Y}=\mathrm{F}(\mathrm{K}, \mathrm{L}) .^{10}
$$

A konstans mérethozadékon túlmenően a termelési függvény további tulajdonságokkal is rendelkezik, mint például a termelési tényezők csökkenő határtermékének feltételezése. Ez matematikailag akkor teljesül, ha a termelési függvény termelési tényezők szerinti elsőrendű parciális deriváltjai pozitívak, míg a másodrendűek negatívak. További elvárás az úgynevezett Inada-kritériumok teljesülése, amelyek biztosítják, hogy az egyensúlyi tőkefelhalmozás véges legyen. Ezek szerint, amennyiben a termelési tényezők mennyisége nagyon alacsony (nullához tart), akkor a határtermékük nagyon magas (végtelenhez konvergál) és fordítva: ${ }^{11}$

$$
\begin{aligned}
& \lim _{K_{t} \rightarrow 0} F_{K}^{\prime}=\infty \\
& \lim _{K_{t} \rightarrow \infty} F_{K}^{\prime}=0 \\
& \lim _{L_{t} \rightarrow 0} F_{L}^{\prime}=\infty \\
& \lim _{L_{t} \rightarrow \infty} F_{L}^{\prime}=0 .
\end{aligned}
$$

Az eredeti Solow-modellben a technológiai haladás külső adottságként, úgynevezett exogén változóként jelenik meg, ami azt jelenti, hogy a modell nem magyarázza. Tekintve ugyanakkor, hogy a technológiai fejlődés hosszú távon javítja a termelési függvényt, ezt a változást közvetett módon azonosítja a modell. A technológiai haladást (A) szokás teljes tényezőtermelékenységnek (TFP - Total Factor Productivity)

8 Lengyel Imre - Kotosz Balázs: Felzárkózás és/vagy távolságtartó követés? A visegrádi országok térségeinek fejlődéséről. Tér és Társadalom, 32. (2018), 1. 5-26.

9 A konvergencia különböző típusairól jó áttekintést adnak például Halmai tanulmányai is. Halmai Péter: Felzárkózás és konvergencia az Európai Unióban. Statisztikai Szemle, 87. (2009), 1. 41-62.; Halmai Péter: Konvergencia és felzárkózás az euróövezetben. Közgazdasági Szemle, 66. (2019), 687-712.

10 Robert Solow: A Contribution to the Theory of Economic Growth. The Quarterly Journal of Economics, 70. (1956), 1. 65-94.

11 Kuncz Izabella: Növekedéselméletek. A humán tôkén innen és túl. Budapest, Budapesti Corvinus Egyetem, Közgazdaságtudományi Kar, Makroökonómia Tanszék, 2017. 
vagy Solow-maradéknak (Solow residuum) is nevezni. Mindezen tulajdonságok figyelembevételével a kibővített Cobb-Douglas-típusú termelési függvény - amely megfelel a fenti elvárásoknak - az alábbi formát ölti:

$$
\mathrm{Y}=A K^{\alpha} \mathrm{L}^{(1-\alpha)}
$$

Átalakítva az egyenletet, a növekedés-számvitel kulcsösszefüggéséhez jutunk, amely már jól mutatja a teljes tényezőtermelékenység kapcsolatát a termelési függvénnyel:

$$
\mathrm{dA} / \mathrm{A}=\mathrm{dY} / \mathrm{Y}-\alpha(\mathrm{dK} / \mathrm{K})-(1-\alpha)(\mathrm{dL} / \mathrm{L}) \text {. }
$$

A teljes tényezőtermelékenység tehát a maradékelvnek megfelelően a gazdasági növekedés azon részét adja, amely nem magyarázható meg a tőke, valamint a munkaerő növekményének hozzájárulásával. ${ }^{12}$

A neoklasszikus modell végső következtetése szerint, ha az országok termelési függvényei, valamint megtakarítási rátái megegyeznek, akkor a kevésbé fejlett gazdaságok hosszú távon fel fognak zárkózni a fejlettebb országokhoz. Ennek oka az, hogy a tőkeállomány alacsonyabb szintjéről induló gazdaságok az egyensúlyi (stacionárius) pálya eléréséig magasabb növekedési ütemet produkálnak, mint a magasabb tőkeállománnyal rendelkező országok. Ezt a jelenséget nevezzük abszolút vagy feltétel nélküli konvergenciának. Abban az esetben viszont, ha az előbb említett változók tekintetében eltérés tapasztalható, akkor minden gazdaság a saját egyensúlyi (stacionárius) állapotához fog közelíteni. Ilyenkor azt mondjuk, hogy relatív vagy feltételes konvergencia érvényesül az országok között.

A neoklasszikus modell következtetései ellenére az elmúlt évtizedekben sok esetben vagy nem volt tapasztalható konvergencia bizonyos országok, illetve régiók között, vagy kifejezetten divergencia (az egyenlőtlenségek növekedése) volt megfigyelhető, amit a Solow-modell sajnálatos módon nem volt képes kielégítően magyarázni. ${ }^{13} \mathrm{Az} 1980$ as évektől kezdődően aztán újabb elméletek jelentek meg, amelyek vagy kibővítették az eredeti neoklasszikus modellt, vagy pedig más aspektusból igyekeztek magyarázatot találni a konvergencia és divergencia jelenségére. ${ }^{14}$

Az endogén növekedéselméletek azokat a tényezőket is megpróbálják magyarázni (endogenizálni), amelyek a korábbi modellekben még exogén változóként jelentek meg. Ennek megfelelően a - teljes tényezőtermelékenységet jelentő - technológiai változást befolyásoló faktorokat is aktívan bekapcsolják az elméletbe. Mankiw, Romer és Weil (1992) szerint igaz ugyan, hogy a Solow-modell jó előrejelzést képes adni az irányokat illetően, a hatások nagyságát már nem igazán tudja kielégítően megbecsülni. Az említett szerzők ezért egy humán tőkével kibővített Solow-modellt javasoltak. ${ }^{15}$ Lucas (1988) a termelési tényezők tekintetében szintén különbséget tesz

\footnotetext{
12 Gregory Mankiw: Makroökonómia. Budapest, Osiris, 2005.

13 Kengyel Ákos: Kohéziós politika és felzárkózás az Európai Unióban. Budapest, Akadémiai Kiadó, 2015.

14 Dedák István: A gazdasági felzárkózás növekedéselméleti összefüggései. Közgazdasági Szemle, 47. (2000), 411-430.

15 Gregory Mankiw - David Romer - David N. Weil: A Contribution to the Empirics of Economic Growth. The Quarterly Journal of Economics, 107. (1992), 2. 407-437.
} 
fizikai és humán tőke között. Utóbbi alatt az egyének általános képességének (tudás, képzettség stb.) szintjét érti, amely szintén módosítja a gazdasági növekedés hosszú távú alakulását. Ezzel összefüggésben intern hatásnak nevezi azt a jelenséget, amely az egyén termelékenységét javítja, extern hatásnak pedig azt, hogy a humán tőke pozitív hatást gyakorol(hat) a többi termelési tényezőre is. ${ }^{16}$ Romer (1990) megfogalmazásában a technológiai változás (javulás) ösztönzést jelent a folyamatos tőkefelhalmozásra, így a tőkeakkumuláció és a technológiai változás együttesen a termelékenység bővülésének jelentős részét adják. ${ }^{17}$

$\mathrm{Az}$ 1990-es évek elején az endogén növekedéselméletek mellett egy másik elméletcsalád is kifejlődött. A Krugman (1991) nevéhez köthető, és mások (pl. Venables és Fujita) által kibővített új gazdaságföldrajzi iskola (New Economic Geography) a gazdasági tevékenységek bizonyos szektorokban és régiókban megfigyelhető térbeli koncentrációját vizsgálja és próbálja magyarázni. ${ }^{18} \mathrm{~A}$ térbeli koncentrációt támogató, illetve az azt akadályozó tényezőket Krugman (1992) a fizikából vett hasonlattal centripetális és centrifugális erőknek nevezi. ${ }^{19}$

Végezetül érdemes megemlíteni az institucionalista elméleteket is, amelyek a szélesebb értelemben vett intézmények (szervezetek, formális és informális szabályok és normák) működését és minőségét teszik meg a növekedés független (magyarázó) változóiként. ${ }^{20}$ Jóllehet az intézmények több szempontból is fontos szerepet játszanak egy gazdaság vagy régió múködésében, a fejlődés perspektívájából nézve elsősorban a tudásteremtést elősegítő intézmények meghatározó jelentőségűek. ${ }^{21}$

Az eddigiekből is látható, hogy a konvergencia/divergencia jelenségét számos elmélet és aspektus alapján meg tudjuk ragadni. Tovább bonyolítja a kérdést, hogy a konvergencia igen sok dimenzióban és sokféle módszertani eszközzel vizsgálható. Jelen tanulmány célja kettős: egyfelől az országokon belüli (regionális) jövedelmi egyenlőtlenségek alakulását, másfelől a makrogazdasági felzárkózás és utolérés folyamatait kívánja megragadni. Ennek megfelelően a regionális, valamint az országos GDP-szinteket és növekedési rátákat alkalmaztuk a számításokhoz.

$\mathrm{Az}$ EU-ban gyakorlati szempontból is különösen fontos a konvergencia megfelelő mértéke, hiszen - ahogyan a bevezetésben is említettük - a nagy fokú gazdasági heterogenitás igen sok probléma forrása lehet. Nem véletlen, hogy a regionális politika szükségessége már az 1980-as években felvetődött a tagállamok részéről, amikor az alacsonyabb fejlettségű mediterrán országok (Görögország, majd Spanyolország

16 Robert Lucas: On the Mechanics of Economic Development. Journal of Monetary Economics, 22. (1988), 1. 3-42.

17 Paul M.Romer: Endogenous Technological Change. Journal of Political Economy, 98. (1990), 5. 71-102.

18 Peter Neary: Of Hype and Hyperbolas: Introducing the New Economic Geography. Journal of Economic Literature, 39. (2001), 2. 536-561.; Paul Krugman: Increasing Returns and Economic Geography. Journal of Political Economy, 99. (1991), 3. 483-499.; Kengyel Ákos: Kohéziós politika és felzárkózás az Európai Unióban. Budapest, Akadémiai Kiadó, 2015.

19 Paul Krugman: A Dynamic Spatial Model. NBER Working Paper, (1992), 4219. 1-60.

$20 \mathrm{Az}$ intézmények hosszú távú növekedésre gyakorolt hatásairól lásd részletesen Acemoglu - Johnson - Robinson (2004) tanulmányát: Daron Acemoglu - Simon Johnson - James Robinson: Institutions as the fundamental cause of long-run-growth. NBER Working Paper, (2004), 10481.

$21 \quad$ Kengyel i. m. (13. lj.) 
és Portugália) csatlakoztak a Európai Közösségekhez. A területi egyenlőtlenségek kérdését, valamint a felzárkózás fontosságát a GMU terve, majd megvalósítása csak tovább fokozta. Ez explicit módon meg is nyilvánult a Maastrichti Szerződésben (MSZ) lefektetett kritériumrendszerben, bár a tagállamok kizárólag nominális feltételeket határoztak meg. Nyilvánvaló azonban (és ez a későbbi kritikákban is megjelent), hogy a reálkonvergencia erősítése legalább olyan fontos, mint a nominális előírásoknak való megfelelés. A GMU-hoz való csatlakozás (az euró bevezetése) ráadásul - az optout záradékkal rendelkező országokat kivéve - minden tagállam, így Magyarország és Csehország számára is kötelező, a kérdés csupán annak időpontja. ${ }^{22}$ Szlovákia ugyan 2009-ben az euróövezet tagja lett, ám a reálkonvergencia fokozása számára is kiemelten fontos. ${ }^{23}$ A reálkonvergencia elősegítésének feladata az EU-n belül jelentős mértékben a regionális (kohéziós) politikára hárul. A különböző alapokból (pl. Európai Regionális Fejlesztési Alap, Kohéziós Alap) rendelkezésre álló források egyszerre próbálják elősegíteni a területi (országon belüli és országok közötti) egyenlőtlenségek csökkentését, valamint felkészíteni az euró bevezetése előtt álló országokat a GMUcsatlakozásra. Kérdés azonban, hogy ezek a célok mennyiben teljesültek és teljesülnek. A következő részben erre próbálunk választ találni, és a három visegrádi tagállam régiói közötti jövedelmi különbségeket elemezzük.

\section{A regionális konvergencia alakulása a három vizsgált országban}

A regionális egyenlőtlenségek vizsgálata többféle statisztikai módszerrel is elvégezhető. Tanulmányunkban az úgynevezett szigma- $(\sigma-)$ konvergencia elemzés segítségével elemezzük a három kis ország területi diszparitásait. A számítás lényege, hogy az egy főre vetített, vásárlóerő-paritáson számított regionális GDP-adatok ${ }^{24}$ logaritmusainak szórását követjük nyomon egy adott idősoron. Abban az esetben, ha a szórás időben csökkenő tendenciát mutat, akkor azt mondjuk, hogy a vizsgált regionális entitások között $\sigma$-konvergencia figyelhető meg. ${ }^{25} \mathrm{~A}$ számításokat így az alábbi összefüggés alapján végezzük el:

\footnotetext{
22 Szijártó Norbert: Az euró bevezetése a közép-kelet-európai régióban - tapasztalatok és kimaradás. Múhelytanulmányok, (2018), 126. 1-74.

23 Ezen túlmenően természetesen a maastrichti kritériumok között szereplő fiskális előírásoknak is folyamatosan meg kell felelnie.

24 A regionális GDP adatok folyó áras aggregátumok.

25 A szigma-konvergencia fogalmáról, elméletéről, illetve különböző változatairól lásd például: Xavier Sala-i-Martin: Regional cohesion: Evidence and theories of regional growth and convergence. European Economic Review, 40, (1996), 6. 1325-1352.; Lengyel Imre - Rechnitzer János: Regionális gazdaságtan. Budapest-Pécs, Dialóg Campus, 2004.; Nemeskéri Zsolt: A régiók fejlődése és konvergenciája Kinában: új eredmények a kínai régiók közötti konvergencia vizsgálatában. Pécs, Regionális Politika és gazdaságtan Doktori Iskola Évkönyve, Pécsi Tudományegyetem Közgazdaságtudományi Kar, 2006.; Philippe Monfort: Convergence of EU regions. Measures and Evolution. Working Papers, (2008), 1. 3-20. vagy Cinzia Alcidi et alii: Income Convergence in the EU: A tale of two speeds. 2018. Elérhető: www.ceps.eu/ ceps-publications/income-convergence-eu-tale-two-speeds/ (A letöltés dátuma: 2020. 10. 05.)
}

Európai Tükör 2020/2. 


$$
\sigma=\sqrt{\sum\left(\ln y_{i}-\ln \bar{y}\right)^{2} / n}
$$

A $\sigma$-konvergencia-számításon túlmenően megvizsgáljuk az egy főre jutó regionális GDP-szintek terjedelmének alakulását is, hogy lássuk, mekkora intervallumban szóródtak az adatok az egyes években. Az adatok a NUTS-2 statisztikai régiókra vonatkoznak. A tanulmány írásakor a legutolsó rendelkezésre álló adat 2017-re vonatkozott, így az idősort eddig az időpontig vizsgáljuk. Ez azonban nem befolyásolja érdemben az eredményeket, hiszen itt egy hosszabb távú trend alapján próbálunk következtetést levonni.

$\mathrm{Az}$ 1. ábra az egyes országok $\sigma$-konvergencia-elemzéseinek eredményét foglalja össze a 2000 és 2017 közötti időszakban.

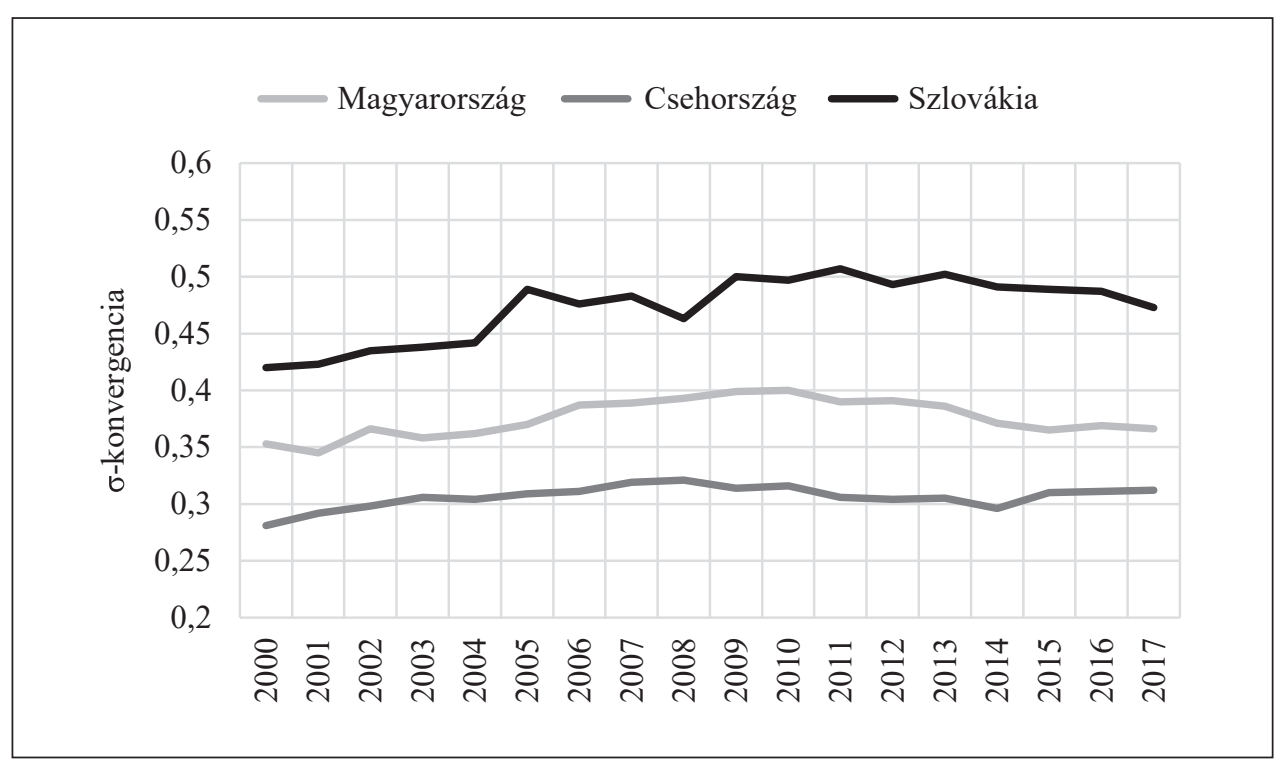

1. ábra

A területi egyenlőtlenségek alakulása a $\sigma$-konvergencia alapján (NUTS-2).

Forrás: Eurostat-adatok alapján a szerző számításai és grafikonja

Mindhárom tagállam esetében azt látjuk, hogy a regionális GDP szórása nemhogy nem csökkent, hanem még enyhén növekedett is 2017-re. Ez a növekedés ugyanakkor Szlovákia esetében volt a legnagyobb. Sajnálatos, hogy az EU-csatlakozást követô években - mindeddig - nem sikerült csökkenteni az országokon belül fennálló területi egyenlőtlenségeket, ami kérdéseket vet fel a regionális politika hatékonyságával és eredményességével kapcsolatban.

Hasonló következtetést vonhatunk le a 2. ábrából is, amely az egy före vetített NUTS-2-adatok terjedelmét (a legmagasabb és a legalacsonyabb jövedelemmel rendelkező régió jövedelmeinek különbségét) mutatja euróban. 


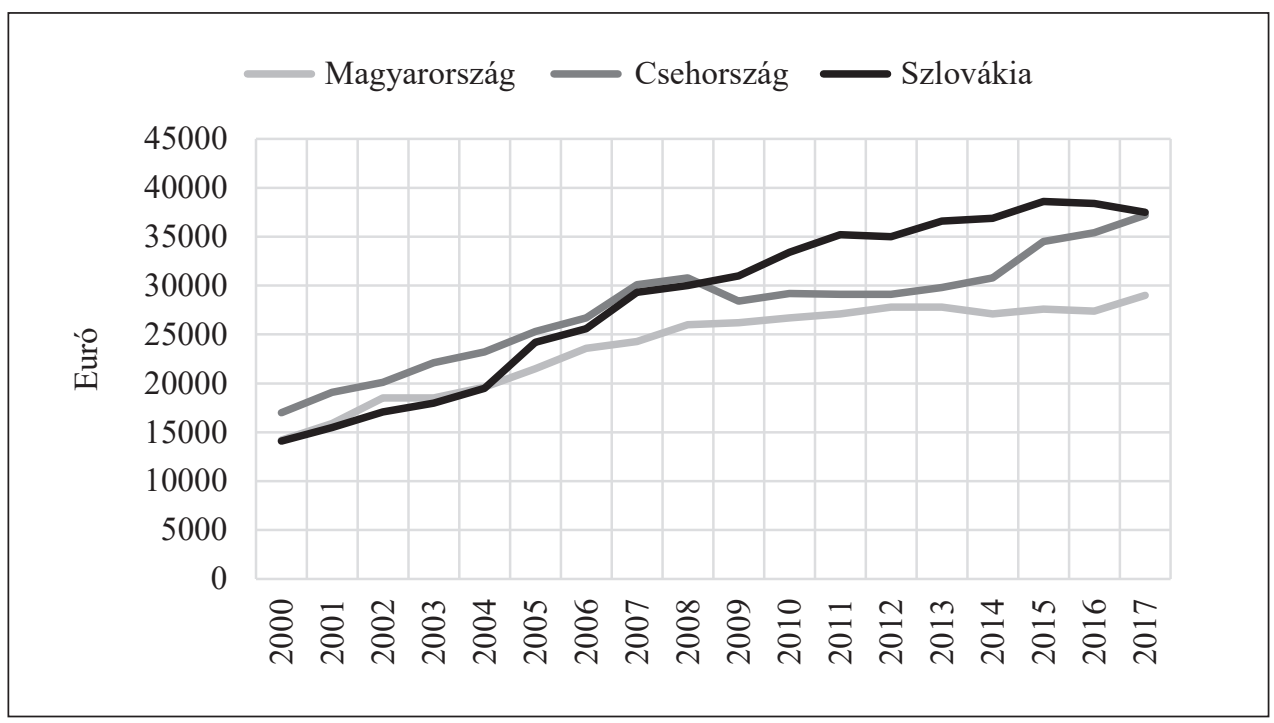

2. ábra

A területi egyenlötlenségek terjedelmének alakulása (NUTS-2).

Forrás: a szerző számításai és grafikonja Eurostat-adatok alapján

Mindhárom visegrádi ország tekintetében a terjedelem növekedését figyelhetjük meg, ugyanakkor a Magyarország régióit reprezentáló görbe alapján az is elmondható, hogy a trendet tekintve hazánk teljesített relatíve a legjobban. Ennek ellenére nem igazán megnyugtató, hogy a három vizsgált kelet-közép-európai ország mindegyikében nőtt a szakadék a leggazdagabb és a legszegényebb régiók között.

A két alkalmazott mutató alapján tehát ugyanarra a következtetésre juthatunk: az uniós csatlakozás és a regionális politika nem járult hozzá érdemben a három tagállamban meglévő területi egyenlőtlenségek csökkentéséhez. ${ }^{26}$

\section{Felzárkózás és utolérés: szcenárióelemzés}

A tagállamokon belüli (regionális) konvergencia elemzése mellett fontos kérdés az is, hogy a visegrádiaknak milyen mértékben sikerült közeledniük az EU28-országok átlagához. A 3. ábra jól mutatja, hogy a konvergencia mindegyik vizsgált tagállam esetén egyértelműen kimutatható. A grafikon tanúsága szerint ugyanakkor ez a folyamat nem (kizárólag) az uniós csatlakozásnak köszönhető, hiszen már a 2004 előtti években is egy folyamatos közeledés volt megfigyelhető. Ezt akár az abszolút konvergencia igazolásaként is értelmezhetjük, amely szerint az alacsonyabb jövedelemmel rendelkező országok hosszabb távon felzárkóznak a gazdagabb államokhoz.

26 Itt két fontos dologra is fel kell hívni a figyelmet. Egyrészt az adatok a revíziókat követően visszamenőleg is változnak az Eurostat adatbázisában, másrészt a konvergenciavizsgálatok sok egyéb mutató és modell alapján is elvégezhetők.

Európai Tükör 2020/2. 


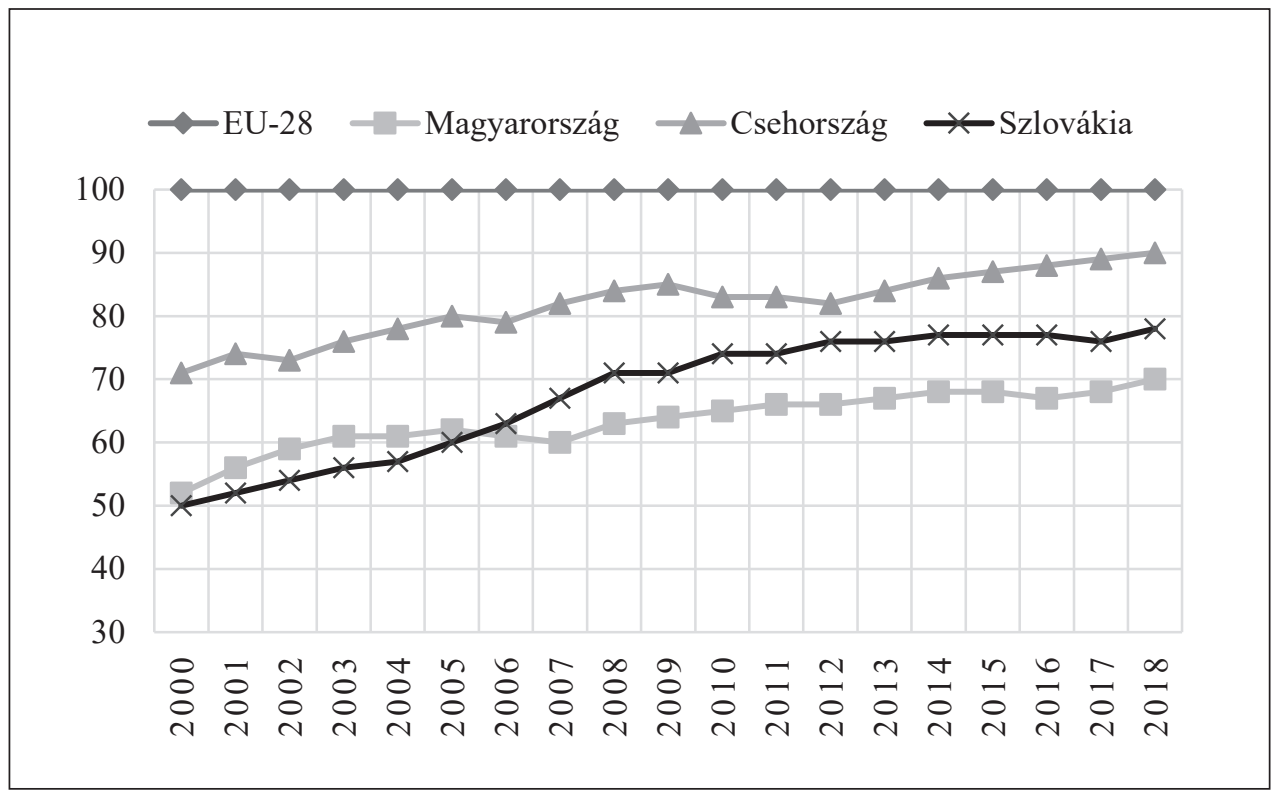

\section{3. ábra}

Az egy före jutó GDP alakulása, PPS (EU28 = 100).

Forrás: a szerző szerkesztése Eurostat-adatok alapján

Az uniós átlaghoz való közeledés kapcsán azonban indokolt kissé árnyalni a képet. A vizsgált időszak kezdetén (2000-ben) Magyarország az EU28 52\%-án, Csehország a 71\%-án, Szlovákia pedig az 50\%-án állt. Csehország tehát - a másik két tagállamhoz viszonyítva - már az időszak elején jelentős előnyben volt, és mindvégig sikerült is megőriznie első helyét. Az időszak végi adatok alapján kis túlzással azt lehet mondani, hogy az ország 2018-ra gyakorlatilag sikeresen felzárkózott az EU-átlaghoz (legalábbis jelentősen megközelítette azt). Hazánk és Szlovákia közel azonos szintről indult. Magyarország 2 százalékpontos előnyben volt, és 2005-ig minden évben magasabb fejlettségi szintet produkált, mint Szlovákia. Ez a tendencia 2006-ban fordult meg, amikor a magyar fejlettség növekedési üteme átmenetileg kissé visszaesett, miközben a szlovák fejlettség egészen 2008-ig meglehetősen dinamikusan nőtt. Szlovákia azóta is folyamatosan - átlagosan körülbelül 8 százalékponttal - magasabb fejlettségi szinteket produkál. Magyarország 2018-ban az EU28 átlag 70\%-án állt, Szlovákia pedig 78\%-os fejlettségi szintre küzdötte fel magát. Az 1. táblázat az időszak elején és végén tapasztalt állapotokat, valamint a változásokat veti össze egymással. 
1. táblázat

Felzárkózási eredmények az egy före jutó GDP alapján (PPS) (EU28 = 100)

\begin{tabular}{|c|c|c|c|}
\hline & $\begin{array}{c}\text { GDP/fö (2000) } \\
\text { (EU28 }=100)\end{array}$ & $\begin{array}{c}\text { GDP/fö (2018) } \\
\text { (EU28 }=100)\end{array}$ & $\begin{array}{c}\text { Differencia } \\
\text { (százalékpont) }\end{array}$ \\
\hline Magyarország & $52(2)$ & $70(3)$ & +18 \\
\hline Csehország & $71(1)$ & $90(1)$ & +19 \\
\hline Szlovákia & $50(3)$ & $78(2)$ & +28 \\
\hline
\end{tabular}

Megjegyzés: a zárójelben lévő számok az országok helyezési sorrendjét mutatják

Forrás: Eurostat adatok alapján saját számítások és táblázat

$\mathrm{Az}$ adatokat összefoglalva megállapítható, hogy a legerőteljesebb konvergenciát Szlovákia volt képes felmutatni (28 százalékpontos változás), míg Magyarország 18, Csehország pedig 19 százalékpontos közeledést ért el. Az eredmények mindhárom ország esetében pozitívak, azonban a konvergencia fokozása céljából továbbra is fontos lenne az uniós átlagnál magasabb növekedési rátákat elérni.

Jogos kérdésként vetődik fel az is, hogy mennyi időre van szükség ahhoz, hogy a felzárkózást maradéktalanul meg tudjuk valósítani. Másként fogalmazva: hány évbe telik mire utolérjük az EU-országok átlagos fejlettségi szintjét. A kérdésre természetesen nem adható pontos válasz, hiszen az utolérés elsősorban attól függ, hogy az elkövetkező időszakban hogyan alakul az egyes tagállamok, valamint az EU átlagos növekedése. Ebben az értelemben a kérdés megválaszolása leginkább egy mozgó célpont követéséhez hasonlítható. Mindazonáltal lehetőség mutatkozik arra, hogy különböző utolérési forgatókönyveket (növekedésiráta-kombinációkat) határozzunk meg. Ily módon lehetőség nyílik rá, hogy egy adott intervallumon belül pozitív, kevésbé pozitív és negatív szcenáriókat vázoljunk fel.

Az alábbiakban egy egyszerübb modell segítségével számítunk lehetséges utolérési pályákat (trajektóriákat). A modell statikus abban az értelemben, hogy az utoléréshez szükséges időtartam minden időpontjára (minden évre) azonos értéken rögzíti az EU, valamint az egyes tagállamok feltételezett gazdasági növekedési ütemeinek kombinációit. Ebben a formában ez természetesen nem reális feltételezés, hiszen a ráták évről évre ingadoznak, azonban több pálya kiszámításával kvantitatív módon megmutatható, hogy a növekedésekben tapasztalható különbségek hogyan befolyásolják az utolérés esélyeit. A modellszámításhoz felhasznált összefüggés Nemes-Nagy (1998) nyomán az alábbi alakban írható fel: ${ }^{27}$

$$
\mathrm{t}=[\log \mathrm{D}(\mathrm{EU} 28)-\log \mathrm{D}(\mathrm{MS})] /\left[\log \mathrm{r}^{(\mathrm{e})}(\mathrm{MS})-\log \mathrm{r}^{(\mathrm{e})}(\mathrm{EU} 28)\right]
$$

Az egyenletben $t$ az utoléréshez szükséges évek számát jelöli, $D(E U 28)$ és $D(M S)$ rendre az EU28 tagállam, valamint az adott tagállam 2018-as fejlettségi szintjét, $r^{(e)}(E U 28)$ és $r^{(e)}$ (MS) pedig a modellszámítás során feltételezett uniós és tagállami (gazdasági) növekedési

\footnotetext{
27 Nemes-Nagy József: A tér a társadalomtudományban. Budapest, Hilscher Rezső Szociálpolitikai Egyesület, 1998.
} 
rátákat. A modellben mind az EU, mind pedig az egyes tagállamok esetében öt különböző növekedési forgatókönyvet feltételezünk, és ezek kombinációiból számítjuk ki az egyes pályákat. A 2., 3. és a 4. táblázat a modellszámítások eredményeit tartalmazza.

2. táblázat

Magyarország lehetséges felzárkózási pályái

\begin{tabular}{|l|c|c|c|c|c|}
\hline & $\mathrm{M}(1)=2 \%$ & $\mathrm{M}(2)=3 \%$ & $\mathrm{M}(3)=4 \%$ & $\mathrm{M}(4)=5 \%$ & $\mathrm{M}(5)=6 \%$ \\
\hline EU28 (1) $=1 \%$ & 36 & 18 & 12 & 9 & 7 \\
\hline EU28 (2) $=2 \%$ & $* * * * * * *$ & 37 & 18 & 12 & 9 \\
\hline EU28 (3) $=3 \%$ & DIV. & $* * * * * * * *$ & 37 & 19 & 12 \\
\hline EU28 (4) $=4 \%$ & DIV. & DIV. & $* * * * * * * *$ & 37 & 19 \\
\hline EU28 (5) $=5 \%$ & DIV. & DIV. & DIV. & $* * * * * * * *$ & 38 \\
\hline
\end{tabular}

Megjegyzés: kerekítettértékek. DIV = divergencia; ${ }^{* * * * * * * *}=$ nincs hatás

Forrás: Nemes-Nagy (1998) i. m. (27. lj.) alapján a szerző modellszámítása

3. táblázat

Csehország lehetséges felzárkózási pályái

\begin{tabular}{|l|c|c|c|c|c|}
\hline & CS (1) $=2 \%$ & CS (2) $=3 \%$ & CS (3) $=4 \%$ & CS (4) $=5 \%$ & CS (5) $=6 \%$ \\
\hline EU28 (1) $=1 \%$ & 11 & 5 & 4 & 3 & 2 \\
\hline EU28 (2) $=2 \%$ & $* * * * * * *$ & 11 & 5 & 4 & 3 \\
\hline EU28 (3) $=3 \%$ & DIV. & $* * * * * * * *$ & 11 & 5 & 4 \\
\hline EU28 (4) $=4 \%$ & DIV. & DIV. & $* * * * * * * *$ & 11 & 6 \\
\hline EU28 (5) $=5 \%$ & DIV. & DIV. & DIV. & $* * * * * * * *$ & 11 \\
\hline
\end{tabular}

Megjegyzés: kerekített értékek. DIV = divergencia; ${ }^{* * * * * * * *}=$ nincs hatás

Forrás: Nemes-Nagy (1998) i. m. (27. lj.) alapján a szerző modellszámítása

4. táblázat

Szlovákia lehetséges felzárkózási pályái

\begin{tabular}{|l|c|c|c|c|c|}
\hline & $S Z(1)=2 \%$ & $S Z(2)=3 \%$ & $S Z(3)=4 \%$ & $S Z(4)=5 \%$ & $S Z(5)=6 \%$ \\
\hline EU28 (1) $=1 \%$ & 25 & 13 & 8 & 6 & 5 \\
\hline EU28 (2) $=2 \%$ & $* * * * * * *$ & 25 & 13 & 9 & 6 \\
\hline EU28 (3) $=3 \%$ & DIV. & $* * * * * * * *$ & 26 & 13 & 9 \\
\hline EU28 (4) $=4 \%$ & DIV. & DIV. & $* * * * * * * *$ & 26 & 13 \\
\hline EU28 (5) $=5 \%$ & DIV. & DIV. & DIV. & $* * * * * * * *$ & 26 \\
\hline
\end{tabular}

Megjegyzés: kerekített értékek. DIV = divergencia; ${ }^{* * * * * * *}=$ nincs hatás

Forrás: Nemes-Nagy (1998) i. m. (27. lj.) alapján a szerző modellszámítása 
A modell eredményeiből két fontos tanulság is levonható. Egyrészt, a konvergencia nem egy rövid távú folyamat, a felzárkózás hosszú éveket, sőt - negatívabb szcenáriók teljesülése esetén - akár évtizedeket vehet igénybe. Ez az eredmény teljes mértékben egybevág a neoklasszikus növekedési modell következtetéseivel. Másrészt, az utoléréshez szükséges évek igen tág intervallumban mozoghatnak attól függően, hogy hogyan alakulnak a növekedési feltételek az egyes országokban, illetve az EU-ban átlagosan. Az utolérés pedig annál gyorsabb, minél nagyobb a növekedési rátákban mutatkozó (tartós) különbség az alacsonyabb jövedelmű országok javára. A vizsgált forgatókönyvek alapján Magyarország felzárkózási időintervalluma 7 és 38 év között mozog, ami rendkívül nagy szóródást jelenít meg. Az viszont elmondható, hogy még a legoptimistább változat esetén is legalább 7 évre van szükség ahhoz, hogy elérjük az EU-országok átlagos fejlettségi szintjét. Ha ennél egy kicsit pesszimistább (és talán reálisabb) forgatókönyvet tekintünk, akkor a teljes konvergencia több mint egy évtized alatt valósulhat meg. Negatívabb változatokkal számolva pedig akár egy 20-30 éves utolérési folyamat sem elképzelhetetlen. Szlovákia esetében szintén elég tág időintervallumot látunk, a lehetséges felzárkózás ideje valahol 5 és 26 év közé becsülhető. Csehország van a legjobb helyzetben, hiszen már nagyon közel van az átlagos uniós fejlettségi szinthez. Ennek megfelelően az utolérési idő a cseh gazdaság számára már lényegesen szűkebb intervallumban mozog (2 és 11 év között). A legoptimistább olvasatban két év múlva beérheti az EU-t, de a legrosszabb szcenárió bekövetkezése esetén sem szükséges több mint egy (bő) évtized. Az eredmények értelmezésével kapcsolatosan ismét hangsúlyozzuk, hogy óvatosan kell eljárni, hiszen egy statikus modellről van szó, amely rögzített feltételekből extrapolál lehetséges változatokat. Ennek ellenére igen hasznos, hogy - még ha csak lehetséges kimenetek formájában is - számszerúsíteni tudjuk az utolérés idejét, ily módon pedig össze tudjuk hasonlítani, és nyomon tudjuk követni a különböző tagállamok teljesítményeit.

Összegezve a tagállami konvergenciák eddigi alakulását, valamint kilátásait azt mondhatjuk, hogy viszonylag jelentős sikerek figyelhetők meg a felzárkózásban, ami mindenképpen valószínúsíti az utolérést mindhárom ország relációjában. Ennek időpontja azonban már nagymértékben eltérhet az egyes államokban. Az utolérés egyedül Csehország esetében került belátható közelségbe, Magyarországon és Szlovákiában viszont minden bizonnyal még hosszabb időt vesz majd igénybe. Ez is rámutat arra, hogy egy magasabb potenciális növekedési ráta elérésére és fenntartására a jövőben (is) nagy hangsúlyt kellene fektetni.

\section{A konvergenciát befolyásoló föbb gazdaságpolitikai összefüggések}

Tanulmányunk célja kifejezetten az volt, hogy néhány egyszerúbb kvantitatív módszer segítségével egy átfogó képet adjunk a konvergenciafolyamat múltbeli alakulásáról, jelenlegi állapotáról, valamint lehetséges jövőbeni kimeneteleiről a három vizsgált tagállamban. Ennek megfelelően nem vizsgáltuk sem az EU, sem pedig az egyes országok konkrét szakpolitikai kereteit, amelyek szerepet játszanak/játszhatnak a konvergencia 
erősítésében. Nem foglalkoztunk továbbá az uniós tagságból eredő potenciális előnyök kiaknázásával sem. Mindazonáltal meg kell jegyezni, hogy ezek természetesen mind olyan jelentős összefüggések, amelyek egyben további kutatási irányok témáját képezhetik. A teljesebb kép kedvéért azonban felhívjuk a figyelmet néhány olyan tényezőre és eredményre, amelyek a felzárkózásnak, illetve a területi egyenlőtlenségek csökkentésének mozgatórugói lehetnek.

A kibővített neoklasszikus növekedési modell kapcsán már utaltunk rá, hogy hosszú távon a teljes tényezőtermelékenység alakulása képes magyarázni a gazdasági növekedés ütemét. A Solow-maradék jelentős részben nem más, mint a termelési függvénynek, azaz a rendelkezésre álló technológiának a javulása. A jobb technológia mögött egyaránt állhatnak fizikai, humán, valamint intézményi tényezők.

A konvergencia elősegítésében és támogatásában mindenképpen kiemelt szerepe van a kutatási és fejlesztési $(\mathrm{K}+\mathrm{F})$, valamint innovációs politikáknak. Ezek eredményeként nem kizárólag a termelés hatékonysága javulhat, de növekedhet a magasabb hozzáadott értéket képviselő termékek és szolgáltatások részaránya is, ami mindenképpen kedvező hatást gyakorol a gazdaságra. Ezzel összefüggésben természetesen nem elhanyagolható terület az oktatás sem, amely bár szintén hosszú távon, de közvetlenül is emeli a humán tőke - mint termelési tényező - minőségét és hatékonyságát. További eredmények érhetők el a konvergencia terén a gazdaságokban rendelkezésre álló digitális, közlekedési és intézményi infrastruktúra bővítésével és javításával. Mindezen tényezők összességében javítják a tagállami versenyképességet, amely végső soron a regionális egyenlőtlenségek csökkenésén túlmenően a magasabb gazdasági növekedési rátákban is visszatükröződhet.

Rapacki és Próchniak (2009) megállapítják, hogy a 2004-es EU-bővítés szignifikáns módon hozzájárult a tíz új tagállam növekedéséhez. A szerzőpáros kvantitatív módszerrel (regresszióvizsgálattal) négy olyan területet azonosít, amely jelentős mértékben fokozta a kelet-közép-európai tagállamok gazdasági növekedését. A külföldi közvetlentőke-befektetések (FDI) beáramlása, a gyorsabb strukturális reformok, a nagyobb gazdasági szabadság, valamint az EU-ból érkező növekvő transzferek mind a növekedés gyorsulásának irányába mutattak. A szerzők ugyanakkor azt is megjegyzik, hogy az EUtagság önmagában még nem garantálja a felzárkózást (a reálkonvergenciát). ${ }^{28}$

Márky (2018) szintén arra a következtetésre jut, hogy a visegrádi országoknak sikerült megközelíteniük a régi tagállamokat, jóllehet a lemaradásuk több területen még mindig jelentős. A szerző a felzárkózás főbb okait a beáramló FDI-beruházásokra, a vállalkozásbarát üzleti környezetre, az alacsonyabb adókra, a beruházás-ösztönző kormányzati tevékenységekre, valamint a közvetlen transzferekre vezeti vissza. ${ }^{29}$

$\mathrm{Az}$ országokon belüli területi egyenlőtlenségek csökkenésével összefüggésben pedig az az empirikus eredmény tűnik elő, hogy az új tagországok azon régiói profitáltak legtöbbet a piachoz való hozzáférésből, amelyek közel helyezkednek el a régi (EU15) tagállamokhoz. Ez többek között igaz Csehországra, illetve Magyarország és Szlovákia

Ryszard Rapacki - Mariusz Próchniak: The EU Enlargement and Economic Growth In the CEE New Member Countries. Economic Papers 367, European Commission, 2009.

29 Márky Zoltán: A Visegrádi Négyek számokban. In Balaskó Angéla (szerk.): A Visegrádi Négyekjelentősége, struktúrája és értékei. Budapest, Külügyi és Külgazdasági Intézet, 2018. 73-80. 
nyugati régióira. Mivel azonban ezekben a régiókban már eleve magasabbak voltak a jövedelmi szintek a szegényebb régiókhoz képest, nem igazán várható a területi konvergencia erősödése. ${ }^{30}$

Látható tehát, hogy a konvergenciát elősegítő tényezők végső soron számos területen jelentkeznek és vizsgálhatók. Tanulmányunk most erre tartalmi és terjedelmi okokból sem vállalkozik. Ennek ellenére a fentiekben említett összefüggések akár együttesen, akár külön-külön is rendkívül érdekes kutatási irányokat jelöl ki. Az eddigiek alapján azt azonban mindenképpen elmondhatjuk, hogy az empirikus megfigyelések összhangban vannak kvantitatív elemzésünk eredményeivel. A felzárkózás terén alapvetően kedvező folyamatok mutathatók ki, a tagállamokon belüli egyenlőtlenségek viszont nem csökkentek.

\section{6. Összegzés, következtetések}

Dolgozatunkban a három visegrádi kis ország (Magyarország, Csehország és Szlovákia) regionális és makrogazdasági konvergenciájának eddigi tapasztalatait vizsgáltuk kvantitatív megközelítésben. Jóllehet a konvergencia teljesítménye számos módon és eszközzel elemezhető, mi alapvetően két területre fókuszáltunk.

A tanulmány első részében egy rövid áttekintést adtunk a konvergencia elméletéről és jelentőségéről, valamint megmutattuk, hogy a tagállamok fejlettségbeli különbségei hogyan kapcsolódnak az EU egészéhez, valamint annak szakpolitikáihoz (a Gazdasági és Monetáris Unióhoz, illetve a regionális politikához).

Ezt követően a tagállamokon belüli területi egyenlőtlenségek időbeli alakulását vizsgáltuk NUTS-2-szinten. A szigmakonvergencia-számítás eredménye, valamint a terjedelmi mutató alapján egyaránt az a következtetés vonható le, hogy a vizsgált időszakban egyik országban sem csökkentek a jövedelmi különbségek (sőt a terjedelem vonatkozásában még nőttek is). Ez mindenképpen kérdéseket vet fel az EU regionális (kohéziós) politikájának hatékonyságával és eredményességével kapcsolatban. Természetesen a vizsgálatokat a jövőben is érdemes lenne újból és újból elvégezni, akár további mutatókat és módszereket is bevonva az elemzésbe.

A regionális egyenlőtlenségeken túlmenően a három tagország felzárkózását is megvizsgáltuk. Megállapítottuk, hogy Magyarország, Csehország, valamint Szlovákia is közeledett az EU28 átlagához az elmúlt két évtized során. Bár ez a folyamat mindenképpen pozitívumként értékelhető, a konvergencia nem tudható be egyértelműen az uniós csatlakozásnak, mivel már 2004 előtt is közeledést lehetett kimutatni.

Ezt követően, a 2018-as fejlettségi szinteket alapul véve különböző utolérési forgatókönyveket határoztunk meg, hogy lássuk, a gazdasági növekedési rátákban mutatkozó különbségek milyen mértékben (és milyen intervallumban) befolyásolják a teljes felzárkózás lehetőségét. A modellszámítások eredményei alátámasztották azt a neoklasszikus növekedési modellből is ismert összefüggést, hogy a felzárkózás meglehetősen hosszú távú folyamat. Ebből a szempontból Csehország van a legjobb helyzetben, Magyarország

30 Annekatrin Niebuhr - Friso Schlitte: EU Enlargement and Convergence: Does Market Access Matter? Eastern European Economics, 47. (2009), 3. 28-56.

Európai Tükör 2020/2. 
és Szlovákia esetében az utolérés viszont várhatóan jóval később fog bekövetkezni. Jóllehet modellünk statikus volt, annyi azonban mindenképp megállapítható, hogy a felzárkózási folyamat gyorsítása érdekében egy viszonylag magas potenciális növekedési ráta elérése és fenntartása kulcsfontosságú lenne a visegrádi országok számára.

A tanulmány utolsó részében a konvergenciát befolyásoló fontosabb gazdaságpolitikai folyamatokról és összefüggésekről adtunk egy átfogó képet, valamint bemutattunk néhány empirikus eredményt. Megállapítottuk, hogy a konvergenciát pozitívan befolyásoló magasabb gazdasági növekedés számos tényezőre vezethető vissza. Annak ellenére, hogy ezeket nem vizsgáltuk részletesen, annyit megállapítottunk, hogy a bemutatott empirikus kutatások alátámasztják a konvergencia alakulására vonatkozó következtetéseinket.

\section{Felhasznált irodalom}

Acemoglu, Daron - Johnson, Simon - Robinson, James: Institutions as the fundamental cause of long-run-growth. NBER Working Paper, (2004), 10481. DOI: https://doi. org/10.3386/w10481

Alcidi, Cinzia - Ferrer, Jorge Núñez - Di Salvo, Mattia - Musmeci, Roberto - Pilati, Marta: Income Convergence in the EU: A tale of two speeds. 2018. Elérhető: www.ceps.eu/ceps-publications/income-convergence-eu-tale-two-speeds/ (A letöltés dátuma. 2020. 10. 05.)

Dedák István: A gazdasági felzárkózás növekedéselméleti összefüggései. Közgazdasági Szemle, 47. (2000), 411-430.

EUROSTAT adatbázisa. Elérhető: https://ec.europa.eu/eurostat

Ferkelt Balázs: Konvergencia az eurózónában a közös pénz bevezetése előtt és után. EU Working Papers, (2005), 4. 1-15.

Halmai Péter: Felzárkózás és konvergencia az Európai Unióban. Statisztikai Szemle, 87. (2009), 1. 41-62.

Halmai Péter: Konvergencia és felzárkózás az euróövezetben. Közgazdasági Szemle, 66. (2019), 687-712. DOI: https://doi.org/10.18414/KSZ.2019.6.687

Horváth Zoltán: Kézikönyv az Európai Unióról. Budapest, HVG-ORAC, 2011.

Kengyel Ákos: Kohéziós politika és felzárkózás az Európai Unióban. Budapest, Akadémiai Kiadó, 2015. DOI: https://doi.org/10.1556/9789630597760

Krugman, Paul: Increasing Returns and Economic Geography. Journal of Political Economy, 99. (1991), 3. 483-499. DOI: https://doi.org/10.1086/261763

Krugman, Paul: A Dynamic Spatial Model. NBER Working Paper, (1992), 4219. 1-60. DOI: https://doi.org/10.3386/w4219

Kuncz Izabella: Növekedéselméletek. A humán tôkén innen és túl. Budapest, Budapesti Corvinus Egyetem, Közgazdaságtudományi Kar, Makroökonómia Tanszék, 2017.

Lengyel Imre - Kotosz Balázs: Felzárkózás és/vagy távolságtartó követés? A visegrádi országok térségeinek fejlődéséről. Tér és Társadalom, 32. (2018), 1. 5-26. DOI: https://doi.org/10.17649/TET.32.1.2910

Lengyel Imre - Rechnitzer János: Regionális gazdaságtan. Budapest-Pécs, Dialóg Campus, 2004. 
Lucas, Robert: On the Mechanics of Economic Development. Journal of Monetary Economics, 22. (1988), 1.3-42. DOI: https://doi.org/10.1016/0304-3932(88)90168-7

Mankiw, Gregory: Makroökonómia. Budapest, Osiris, 2005.

Mankiw, Gregory - Romer, David - N. Weil, David: A Contribution to the Empirics of Economic Growth. The Quarterly Journal of Economics, 107. (1992), 2. 407-437. DOI: https://doi.org/10.2307/2118477

Márky Zoltán: A Visegrádi Négyek számokban. In Balaskó Angéla (szerk.): A Visegrádi Négyek jelentösége, struktúrája és értékei. Budapest, Külügyi és Külgazdasági Intézet, 2018. 73-80.

Monfort, Philippe: Convergence of EU regions. Measures and Evolution. Working Papers, (2008), 1. 3-20.

Neary, Peter: Of Hype and Hyperbolas: Introducing the New Economic Geography. Journal of Economic Literature, 39. (2001), 2. 536-561. DOI: https://doi.org/10.1257/ jel.39.2.536

Nemeskéri Zsolt: A régiók fejlődése és konvergenciája Kínában: új eredmények a kínai régiók közötti konvergencia vizsgálatában. Pécs, Regionális Politika és gazdaságtan Doktori Iskola Évkönyve, Pécsi Tudományegyetem Közgazdaságtudományi Kar, 2006.

Nemes-Nagy József: A tér a társadalomtudományban. Budapest, Hilscher Rezső Szociálpolitikai Egyesület, 1998.

Niebuhr, Annekatrin - Schlitte, Friso: EU Enlargement and Convergence: Does Market Access Matter? Eastern European Economics, 47. (2009), 3. 28-56. DOI: https://doi. org/10.2753/EEE0012-8775470302

Rapacki, Ryszard - Próchniak, Mariusz: The EU Enlargement and Economic Growth In the CEE New Member Countries. Economic Papers 367, European Commission, 2009. DOI: https://doi.org/10.2765/23063

Romer, Paul M.: Endogenous Technological Change. Journal of Political Economy, 98. (1990), 5. 71-102. DOI: https://doi.org/10.1086/261725

Sala-i-Martin, Xavier: Regional cohesion: Evidence and theories of regional growth and convergence. European Economic Review, 40. (1996), 6. 1325-1352. DOI: https://doi. org/10.1016/0014-2921(95)00029-1

Solow, Robert: A Contribution to the Theory of Economic Growth. The Quarterly Journal of Economics, 70. (1956), 1. 65-94. DOI: https://doi.org/10.2307/1884513

Szijártó Norbert: Az euró bevezetése a közép-kelet-európai régióban - tapasztalatok és kimaradás. Múhelytanulmányok, (2018), 126. 1-74. 